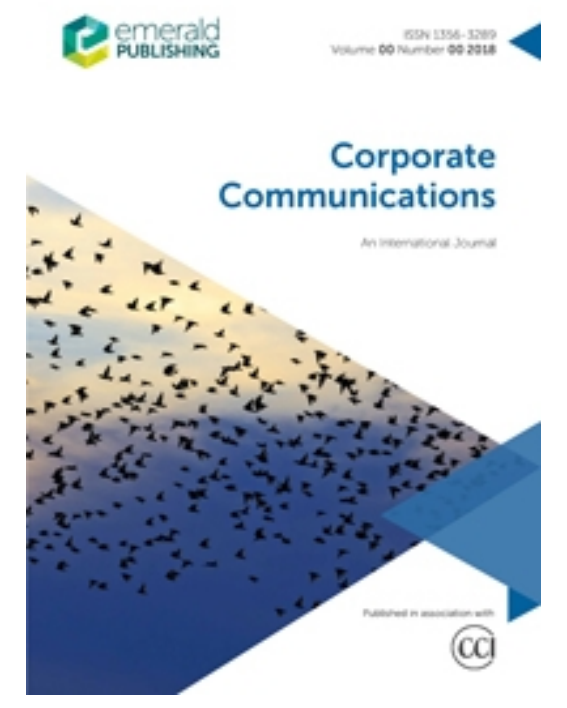

\title{
Chartered Status and public relations' struggle for legitimacy
}

\begin{tabular}{|r|l|}
\hline Journal: & Corporate Communications: an International Journal \\
\hline Manuscript ID & CCIJ-11-2019-0130.R3 \\
\hline Manuscript Type: & Original Article \\
\hline Keywords: & charter, legitimacy, profession, chartered, professional project, Ethics \\
\hline \multicolumn{2}{|r}{} \\
\end{tabular}

\section{SCHOLARONE ${ }^{m}$ Manuscripts}




\title{
Chartered status and public relations' struggle for legitimacy
}

\author{
Abstract \\ Purpose - To appraise progress towards 'the professional project' for the public relations \\ profession in the UK using the Royal Charter application as a pivotal assessment point in the \\ journey.
}

Design/methodology/approach - Primary and secondary, qualitative research, with participant observation and chronological and thematic analysis of archival documents at the time of the Charter process: 2003 to 2005. Two expert interviews were also conducted for a view on progress. The study is contextualised within the professions literature and the 2019 State of the Profession study undertaken by the Chartered Institute of Public Relations. Findings - The Institute faced significant challenges during the Charter application raised by Institutions such as the Government Department for Education and Skills, including the diversity of the profession, standards of education and training, practitioner standards, including ethical, as indicated by their levels of membership and commitment to ongoing professional development. The profession is making limited progress towards legitimacy. Continued press ambivalence, recent scandals, such as the Bell Pottinger affair in South Africa and jurisdictional infringement by other professions continue to threaten its attempts to move towards social closure.

Research limitations/implications - These areas of challenge i.e. diversity, social acceptance, qualifications and professional progress remain and provide an ongoing research agenda.

Practical implications - Social acceptance, qualifications and professional progress remain elusive for the practice and more radical action is required to achieve progress.

Originality/value - This is the first academic article to chronical the charter journey using the original documentation as source materials and the first to review progress towards the goals that chartered status signified for public relations.

Keywords Charter, chartered, legitimacy, profession, professional project, ethics Paper type Research paper

\section{Introduction}

At the Annual General Meeting of the Institute of Public Relations on $14^{\text {th }}$ June 2005, the Deputy Clerk to the Privy Council handed over to the Immediate Past President a framed, vellum declaration embossed with the Queen's own signature and Great Seal. This was a Royal Charter stating that the Institute was now a chartered body. Receipt of this document was preceded by two years of intense work led by the Immediate Past President who had submitted the formal application.

The application and achievement of chartered status was a major milestone for the Institute and for the profession ${ }^{1}$. Its bestowal was seen to endow a level of legitimacy that had eluded the practice and its representative bodies. Internally, part of the impetus for pursuing chartered status was a desire by the Institute to separate practitioners who were members from those who were not: members were professionals; those who were not, were open to having their professionalism challenged.

This article sets out to do four things: first, to chart the course of the journey to chartered status. Second, to set that within the broader context of the literature on the professions and the issues that arise from that literature. Third, to analyse progress towards public relations' acceptance as a profession based on the challenges that faced it before charter and the current 
ones, and fourth to draw some conclusions and recommend some further steps, which may build towards and accelerate progress.

The article is the first to chronical in an academic journal the charter journey using the original documentation as source materials, and the first to review progress towards the goals that chartered status signified in the public relations field.

\section{Literature review}

This overview of the literature on the professions and professionalism is deliberately nonexhaustive since extensive reviews on the topic and how it applies to public relations have been provided earlier (Pieczka and L'Etang, 2006; Edwards, 2018). The perspective taken here is from the sociology of the professions and in particular the notion of the professional project (Larson, 1977; 2012) and the system of professions (Abbott, 1988). For ease of reference, both approaches are given the umbrella term the professional project in this article, but it is important to explain the differences. The professional project is centred on 'the market' around which economy, society and professions are organised and its end is to control the market and complete 'social closure', that is, elite status. Foundational to Larson's $(1977 ; 2012)$ position are two propositions: professional knowledge, both learned and practical, and training, which produces a marketable product that is valued. Abbott's (1988) system of professions also has two tenets, first that professions evolve depending on the interrelationship they have with other actors, and second that professional work consists of tasks, which a profession successfully claims for itself. Combining these two notions is helpful in that the process of being recognised as a profession, or professionalisation as it is often called, is about an occupation's ongoing struggle to secure its jurisdictional borders (boundaries of the profession), to capture a position in the market and to obtain social recognition and approval for its work, in other words, legitimacy. Professionalisation is seen to be a 'cure' for the lack of legitimacy that public relations suffers from (Pieczka and L'Etang, 2006; Merkelsen, 2011; Edwards and Pieczka, 2013; Taylor and Kent, 2016)

It is helpful to note the definition of a profession given by Friedson (1970):

.....an occupation which has assumed a dominant position in the division of labor so that it gains control over the determination and substance of its own work (p.xv11)

There are a number of facets that define a profession and which emerge from the literature: jurisdiction over a particular occupational field; a code of ethics, a body of theoretical knowledge, formal and recognised (certified) training; closed entry; a public service orientation and a representative professional body (Wylie, 1994; Pieczka and L'Etang, 2006; Taylor and Kent, 2016; Edwards, 2018; Bourne, 2019).

As a number of researchers in the professions field (Johnson, 1972; Abbott, 1988; Friedson, 1986, 2001; Macdonald, 1995; Brock \& Saks, 2016; Larson, 2012; Saks, 2012, 2016) and in public relations (Pieczka and L'Etang, 2006; Waeraas, 2007; Edwards 2014, 2018; Fitch, 2014; Edwards and Pieczka, 2013; Merkelsen, 2011; Bourne, 2019) have asserted, legitimacy and control over jurisdiction are important because these provide the routes to esteem, an ability to corner the market and hence, potentially high rewards for those at the apex of the hierarchy both between and within professions.

The challenge that professions and professionals face is to secure legitimacy at three levels from society (macro), their organisation (meso) and as individuals (micro) (Merkelsen, 2011; 
Edwards, 2018). This then gives them a licence and mandate, that is, to carry out their work in exchange for money and to define for themselves and others what constitutes proper conduct in relation to that work (Pieczka and L'Etang, 2006). Legitimacy is defined as:

A generalised perception or assumption that the actions of an entity are desirable, proper, or appropriate within some socially constructed system of norms, values, beliefs, and definitions. (Suchman, 1995, p. 574)

Once this has been achieved and is secured over time, a profession becomes institutionalised, that is it receives societal approval and there is a general belief that 'things cannot be otherwise': a taken for grantedness that they should do their work that is not challengeable. Their legitimacy is then re-enforced by them enacting the role that society has agreed it should enact and which it self-affirms on a continuing basis (Deephouse and Suchman, 2008; Lawrence and Suddeby, 2006; Scott, 2008; Sandhu, 2009; Gregory, Invernizzi and Romenti, 2013). However, as Abbott (1988) states, professions are not static, they change depending on social context and the regulatory, competitive and sector environments in which they operate. Therefore, they are constantly evolving, albeit at a slower or faster pace depending on that environment.

Professions are not all the same. Medicine and law can be seen as the 'top of the pecking order' (sic) (Johnson, 1972; Saks, 2015; Brock and Saks, 2016) and can be seen as ideal types to which most professions would aspire. They have long-standing and extensive bodies of knowledge with active strands of research, certificated education, training, are regulated, have clear and enforced codes of ethics and their professional associations have coercive and symbolic power. Their practitioners are seen as elite and are well remunerated. Significantly, they have social approval, and control their jurisdictional boundaries fiercely: note the battles that the para medical professions and particularly alternative medicine practitioners have with doctors (Saks, 2015).

Edwards (2018) categorises public relations as a modern, knowledge-based occupation alongside others such management consultancy, project management and recruitment. There are a number of characteristics that distinguish these types of professions from the more established ones such as law and medicine: a fluid body of knowledge; few barriers to entry; and, non-mandatory ongoing continuing professional development (CPD) and education.

The public relations literature about the professional project (for example, Pieczka and L'Etang, 2006; Edwards 2018; Fitch, 2014; Edwards and Pieczka, 2013; Bourne, 2019), which is limited, highlights a number of issues with the most pertinent to this article being now identified.

First, jurisdictional boundaries (Edwards, 2018; Bourne, 2019). These are constantly being challenged not only by other professions such as management consultancy, event management and personnel development/HR, but because of changes in the environment. Advances in technology such as automation, machine learning and Artificial Intelligence (AI) now means that IT professionals encroach in on-line work; the integration of communication platforms means that marketing, always a jurisdictional threat, has been further empowered; the increased demand for 'story-telling' has given new opportunities for journalists to enter or claim a part of the profession. 
Second, issues of closure. Both the professions and public relations literature recognises this (Brock and Saks, 2016, Saks 2016; Edwards and Pieczka, 2013; Edwards, 2014; Bourne, 2019). Closure takes two dimensions, first barriers to enter and to progress in the profession are not just educational achievement and subject expertise, but class, gender, disability, geography in fact anything that does not conform to the stereo type of mainly middle-class, white and usually male, although some progress has been made on gender. These issues are not confined to external, and particularly client/employer perceptions of what is preferred, but are constantly re-produced in the profession's own publications and discourses (Edwards and Pieczka, 2015). The second dimension of closure is social. By that is meant that the profession is institutionalised and it and its professional body are regarded as pre-eminent in the occupational field. Its legitimacy is not challenged. The literature (Larson, 1977; Pieczka and L'Etang, 2006; Waeraas, 2007; Fitch, 2014; Edwards and Pieczka, 2013; Bourne, 2019) notes much dispute about this, some of which is highlighted above in the discussion about jurisdiction, but also public relations has not achieved social acceptance partly because of ethical issues as outlined below.

Third, body of knowledge and education. There has been significant progress in developing the body of knowledge in the UK and diversifying the theoretical base of public relations as exampled by the expanding number of academic textbooks, journals and conferences in the field over the last 20 years. However, there is still evidence of antiintellectualism in the practitioner community (Gregory and Fawkes, 2019). Interestingly, there is a distinction between what even senior practitioners actually do for the vast majority of their time, which is copywriting, editing and media relations, and what recruiters say they want, which is strategic thinking and planning and business management (CIPR, 2019)

There have also been more systematic attempts to influence and standardise the curricula of universities, for example, the Commission for Public Relations Education (2017) produced guidelines for undergraduate education which were ascribed to by many professional associations internationally and these associations in turn certify courses run by universities (Fitch, 2014). The issue here is that many employers and recruiters do not require their entrylevel professionals to have degrees in public relations; in fact, there is evidence that they ignore them or even positively recruit those from other disciplines (CIPR, 2019).

The professional associations themselves have developed a range of professional qualifications, for example the Universal Accreditation Board (UAB) runs the Accredited Practitioner course (APR) across the world on behalf of associations such as the Public Relations Society of America. The CIPR has developed its own suite of post-graduate qualifications, including at certificate and diploma levels. Individual associations offer a variety of long or short courses based on various competency and capability frameworks, the latest of which was developed by the Global Alliance ${ }^{2}$ (GA, 2018).

Fourth, ethics. The literature enumerates the many challenges to the practice of public relations, from general charges of spin and deception, to defence of bad corporate and political behaviour to unacceptable and large scale manipulation of public opinion (Stauber and Rampton, 2004; Dinan and Miller, 2007; Miller and Dinan, 2008: Doorley and Garcia, 2010; Taylor and Kent, 2016; Economist, 2017; Edwards, 2018). This impacts on the prospects for public relations to gain social acceptability and on the status of professionals in organisations and as individuals. This is also an element in the discussion in many of the conversations within the profession on its name and whether a name change will help to distance itself from the worst practices. 
Having identified the setting provided by the literature for the consideration of chartered status, methodology is now discussed.

\section{Methodology}

The overall methodology is qualitative and brings together a number of elements. It is ethnographic in that the author was the President of the Institute of Public Relations when it applied for chartered status and therefore has direct participant observer insights into the process. She has also been a participant and non-participant observer of the progress of the profession for 26 years having held various offices in both the national professional association in the field and the Global Alliance, the UN recognised Non-Governmental Organisation (NGO), which represents the worldwide community of professional associations.

The study also includes archival research. The author maintained a personal archive of Institute documents and correspondence from 2003 to 2005, which is the period, covered by the Charter application process, since she was the official signatory of the Petition to the Queen and had to approve all documentation related to it. This archive was supplemented by documents requested from and provided by the Institute at the time and in the year following the Charter Application, for example, internal memos between Institute staff and between the Institute and the Department for Education and Skills. In sum, 54 documents have been analysed, which although not cannot be claimed to be the exhaustive record, contains enough data for a comprehensive and triangulated picture to be drawn, with many documents crossreferencing and clearly following-on from others. These documents consist of the official reports of process and progress that were made to the Institute's Executive Committee, Board and Council and to the AGMs in 2003, 2004 and 2005; letters and reports of telephone calls and meetings between the Institute and Privy Council; correspondence between the Institute and government departments and bodies; letters to and from other individuals consulted; informal and formal correspondence between the author, Director General of the Institute and the Institute's lawyer who were the main Institute actors involved in these events; drafts and final versions of the formal documents which constituted the Charter submission and internal correspondence with Institute staff.

These documents were reviewed to determine the chronology of events leading to the Charter submission and subsequent events, and to confirm the areas of concern that were raised during the application process. Thus, both a chronological and thematic analysis was undertaken of the documentation, with the thematic analysis focussing on the issues raised by those challenging the submission, principally the Department of Trade \& Industry (DTI).

While the author recognises the difficulties of using archival research (Cook, 2001; L'Etang, 2008; King, 2012; Fitch 2014) such as its completeness and its reliance on those who use it to be honest, many of these documents, for example the papers for committee meetings, and the Charter documents were and are a matter of public record.

To provide an indicator of progress in the professional project since a charter was awarded, the CIPR's State of the Profession 2019 report (CIPR, 2019) was used. This is an independent, annual survey of members and non-members conducted by a commercial research company that looks at the profile and scope of the profession and investigates issues of contemporary concern. There were 1,500 respondents to the 2019 survey, which equates to $15 \%$ of the membership. 
To add further context, nuance and data to this survey, semi-structured interviews of one hour and 45 minutes respectively were conducted with the current CEO and the Director of Professional Development and Membership of the CIPR. Neither of these individuals were employed by the Institute or in any way connected with the charter process, but, being employees of over five years' standing and at a senior level, they were be able to provide an expert and contemporary view on the Institute's current progress. They were involved in commissioning the State Of The Profession survey and, because of their roles in the Institute and being connected with other professional associations and accrediting bodies, were well positioned to provide an informed view. The interview with the CEO covered the issues that were raised as challenges during the charter process (outlined below). The Director of Development and Membership provided data concerning uptake in qualifications and membership categories and additional trend and attitudinal information about education and training more broadly.

\section{Context}

Before providing the detail of this particular charter journey, it is important to set some context, both of the institute's history and the process itself.

Founded in 1948, the Institute of Public Relations had its roots in the public sector, with a group of public relations officers from within local government providing the impetus for its establishment. Furthermore, largely because of its historic roots, the orientation of public relations in the UK has traditionally been towards promoting the public rather than private (that is, corporate) interest and was always been much broader in conception than in the US with its emphasis on media relations. However, in the 1980's there was significant growth in demand for public relations as corporate departments and consultancies became established in the UK (Edwards, 2014) and this coincided with the arrival of some of the large and influential US consultancies (e.g., Burson-Marsteller, Hill and Knowlton, Edelman and Fleishman-Hillard) who worked mainly for the private sector including the large, newly privatised public sector companies (a Thatcher Government priority) and the burgeoning financial sector. The late 1990's and early 2000's were periods of economic growth which again added numbers to the profession and by 2004, the Institute had 7,500 members, which represented a $50 \%$ increase in the previous 5 years (IPR, 2004a).

The Institute had made previous unsuccessful, informal moves to obtain a charter in the 1950's and 1970's, but an application in 2004 appeared more auspicious. Informal soundings made to the Privy Council from 2000 onwards indicated the door was not closed. At the end of 2002, a new President-Elect was voted-in to take office in 2004, whose main platform was to apply for chartered status and in 2003, an important research report jointly funded by the then DTI and IPR had showed the importance of the industry as a mature contributor to the UK economy and society. The DTI report was important to the charter initiative not only because of its convincing content, but because the Department became a sponsor for the IPR in the application process.

The charter process itself is not straightforward. Chartered organisations are a development of the guilds of the $12^{\text {th }}$ Century in the UK, which were organisations run for and by craftsmen, tradesmen and merchants such as wool merchants, bankers, blacksmiths, weavers, butchers and stonemasons. They existed to oversee and protect their trade and operated welfare and disciplinary regimes. 
Royal Charters date from the $13^{\text {th }}$ Century. They were originally granted to create private or public corporations including towns and cities, and defined their purpose and privileges. Today, however,

New charters are normally reserved for bodies that work in the public interest (such as professional institutions and charities) and which can demonstrate pre-eminence, stability and permanence in their particular field. (Privy Council, 2019)

Royal Charters are granted by the Sovereign acting on the advice of the Privy Council. The Privy Council dates back to the $12^{\text {th }}$ Century and now deals with business, which for historical reasons, is not covered by individual departments of Government: Royal Charters come under that heading. Ministers in Government serve as Privy Councillors and they provide advice to the Queen because constitutionally she is only able to act on that advice. In light of this process, charter applications have to be undertaken advisedly and with prospects of success. It would be an embarrassment if the Queen were to refuse a petition for a Royal Charter, for all concerned, but particularly for her, and that is to be avoided.

\section{The Charter process.}

Applying for a charter is an exacting exercise and the Privy Council make it clear that not many submissions go forwards. Even if their basic criteria are met, success is not guaranteed.

Enquiries about obtaining a charter first take the form of informal soundings to the Privy Council Office. In this case, enquiries began in 2000 when the Institute was advised that the time was not right for a submission, but that it should carry on with its developments, particularly in the area of professional development where it was undertaking significant revisions.

As part of these ongoing informal discussions, in March 2003 the Institute was advised that the criteria applied by the Privy Council Office with regard to charter had become more 'flexible', but that there were a number of key questions that would need addressing. First, how representative was the IPR of the profession? Second, was it the 'voice' of the profession? Third, were membership admission rules robust? Inherent in that question was the issue of qualifications for entry because the working criteria for the Privy Council was a membership of 5,000 at least $75 \%$ of whom should have a relevant first degree. Fourth, was the Institute committed to education and training? Fifth, was there a clear Government/national interest in regulating the profession?

After approval at the Institute's AGM in May 2003 that a charter application should be progressed, an explanatory letter was sent to the Clerk of the Privy Council on $21^{\text {st }}$ May outlining an initial response to these questions. It outlined the broad nature of public relations work, the different job titles that practitioners had, but the desirability, in the public interest, of having a recognised profession that differentiated itself for qualified (to enter) and unqualified practitioners. It also outlined the breadth of membership, links to international associations such as the then existing Confederation of European Public Relations (CERP), and the Global Alliance along with evidence that other such national public relations associations were looking to the IPR as a model of a well-run professional body. Educational activities such as validation of undergraduate and post graduate degrees, the running of its own certificate and diploma and an accredited continuing professional development scheme (a world first in the sector) were offered as evidence of professional activity as were various policy initiatives, including the DTI Report mentioned above and thought-leadership in 
evaluation, good conduct in lobbying, and non-financial reporting. The letter was copied to the DTI, who had agreed to be the Government sponsor for the charter and to Mike Grannatt, the Director General of the Government Information and Communication Service and a key advocate.

The letter was well received by the Clerk to the Privy Council in general, but he stated that the main factor for his consideration was whether the granting of a charter would take forward the Government policy aims (unspecified) and be in the public interest. He informed the Institute that he would take advice from those copied into the letter and other advisers, including from the Department for Education and Skills (DfES).

While awaiting the results of this consultation, in July 2003 the Institute's Executive Committee (IPR, 2003) authorised the Director General to begin work on re-casting of its Memorandum and Articles into a Charter, equivalent to a statement of purpose, and By-Laws, which together form the constitution of a chartered body. This is a large task and requires specific legal advice. These two documents are supported by a detailed set of Regulations, which are in effect the governance 'operating manual'.

The Institute was also advised by the Privy Council to take soundings from other professional bodies and interested parties whose jurisdiction might overlap with its own, particularly the Chartered Institute of Marketing, Public Relations Consultants Association and the various advertising associations since they had the right to counter-petition. If that had happened, the application would have been unlikely to go forwards 'since it is not desirable to involve The Queen in controversy' (Letter from Privy Council to DTI, $18^{\text {th }}$ June 2003).

Responses from both the DTI and Mike Grannatt were positive and no objections were registered from the contiguous professional associations.

Over the autumn and winter of 2003/2004, detailed documentation was prepared, including the Petition to the Queen, the Charter, By-Laws and Regulations. Members of the Institute were consulted in the Spring of 2004 and with the support of the Board and Council, the changes to the legal basis of the Institute to a Chartered body were agreed at the AGM on $23^{\text {rd }}$ June 2004 and the application submitted to the Privy Council on $9^{\text {th }}$ July 2004 . In moving the resolution for applying for a charter the President said

The time is right to establish a Chartered Institute which will put clear water between qualified and unqualified PR practitioners, and work in the public interest to promote the highest standards of ethical public relations practice. The Institute has grown in strength and numbers over the past five years and can provide the leadership needed to promote the development of a qualified and regulated profession. (IPR, 2004b)

Following an application, the Privy Council then publishes the fact that it has been made in The Gazette, which is the official public record, so that anyone with objections can raise them. This was done on $30^{\text {th }}$ July 2004. It was also in July, and surprisingly given it had been consulted earlier, that the DfES came forward with a number of challenges.

It was concerned about diversity; questioned the membership classes the Institute had and particularly, wanted to be assured that users of public relations services had a clear 
understanding of what is to be expected from different tiers of membership; it wanted see high value put on the designation Chartered Practitioner as a signifier that those individuals had the highest standards of service quality, integrity and professional competence and that the route to achieving chartered status was rigorous, including a commitment to continuing professional development. The public should be in no doubt that Chartered Practitioners were seen to be in a class of their own, separate from all other types of membership.

The DfES also wanted assurance of the standards in the Institute's own education and training and that of other providers, which it accredited. It wanted a tightening up of administrative procedures to conform to the recommendations of a Qualifications and Curriculum Authority (QCA) (national qualifications regulator) inspection of its Advanced Certificate qualification. Interestingly, the Department wanted the Institute's CPD offering to include significant elements of management and leadership.

An important issue the Department saw was a potential conflict of interest between the Institute being both an accreditor of programmes, for example at universities, and a provider of them and new governance structures should to be put in place to ensure a proper separation of these powers.

After a number of discussions between the department, the QCA and action being taken by the Institute, all parties agreed that there was sufficient rigour in place. The results were then presented to the Privy Council and following approval of both the Charter and the By-Laws by them, on $9^{\text {th }}$ February 2005 a petition for a Royal Charter was approved by the Queen in Council (i.e. in the presence and on the advice of the Privy Council). This was notified to the IPR in February 2005 and the Royal Charter, signed by and with the Royal Seal of the Queen, was delivered to the now Chartered Institute of Public Relations on 14 $4^{\text {th }}$ June 2005.

To aid understanding, a timeline with the key events of the charter application process is given in Figure 1. 


\begin{tabular}{|c|c|c|c|c|c|c|c|c|c|c|}
\hline Sept 2002 & Mar 2003 & May 2003 & $\begin{array}{l}\text { Autumn/winter } \\
2003 / 2004\end{array}$ & Spring 2004 & 23 June 2004 & 9 July 2004 & July 2004 & $\begin{array}{l}\text { Autumn } \\
2004\end{array}$ & $\begin{array}{l}9 \text { Feb } \\
2005\end{array}$ & $\begin{array}{l}14^{\text {th }} \\
\text { June } \\
2005\end{array}$ \\
\hline $\begin{array}{l}\text { New } \\
\text { President } \\
\text { of the } \\
\text { Institute } \\
\text { elected for } \\
2004 \text { on a } \\
\text { mandate to } \\
\text { seek } \\
\text { chartered } \\
\text { status }\end{array}$ & $\begin{array}{l}\text { Privy } \\
\text { Council } \\
\text { indicates } \\
\text { more flexible } \\
\text { approach to } \\
\text { considering } \\
\text { charter } \\
\text { applications }\end{array}$ & $\begin{array}{l}\text { Following } \\
\text { approval to } \\
\text { proceed at its } \\
\text { AGM, } \\
\text { Institute } \\
\text { sends Privy } \\
\text { Council a } \\
\text { paper, 'The } \\
\text { IPR case for } \\
\text { a Royal } \\
\text { Charter'. } \\
\text { Privy Council } \\
\text { uses paper as } \\
\text { basis of } \\
\text { consultation } \\
\text { with relevant } \\
\text { government } \\
\text { departments } \\
\text { \& advisers. }\end{array}$ & $\begin{array}{l}\text { After positive } \\
\text { indications from } \\
\text { Privy Council, } \\
\text { IPR begins } \\
\text { consultation with } \\
\text { other professional } \\
\text { bodies and } \\
\text { interested parties } \\
\text { (e.g. CIM, } \\
\text { PRCA). Detailed } \\
\text { drafting of } \\
\text { charter } \\
\text { documentation } \\
\text { commences. }\end{array}$ & $\begin{array}{l}\text { Consultation } \\
\text { with IPR } \\
\text { members } \\
\text { after Council } \\
\text { approves } \\
\text { draft charter } \\
\text { documents. }\end{array}$ & $\begin{array}{l}\text { IPR AGM } \\
\text { approves change } \\
\text { in legal basis of } \\
\text { Institute and } \\
\text { application for } \\
\text { charter } \\
\text { submission, } \\
\text { including all } \\
\text { documentation. }\end{array}$ & $\begin{array}{l}\text { Charter } \\
\text { application } \\
\text { submitted } \\
\text { to Privy } \\
\text { Council }\end{array}$ & $\begin{array}{l}\text { Questions } \\
\text { raised by } \\
\text { DfES. } \\
\text { Notice } \\
\text { placed in } \\
\text { The } \\
\text { Gazette } \\
30^{\text {th }} \text { July. }\end{array}$ & $\begin{array}{l}\text { Resolution } \\
\text { of issues } \\
\text { raised by } \\
\text { DfES }\end{array}$ & $\begin{array}{l}\text { Charter } \\
\text { petition } \\
\text { approved } \\
\text { by the } \\
\text { Queen in } \\
\text { Council }\end{array}$ & $\begin{array}{l}\text { Royal } \\
\text { Charter } \\
\text { presented } \\
\text { to the } \\
\text { Institute } \\
\text { at the } \\
\text { AGM. }\end{array}$ \\
\hline
\end{tabular}

Figure 1. Timeline of main events of the Charter application process. 


\section{Benefits and obligations of obtaining a Royal Charter}

Obtaining chartered status brought a number of benefits and consequences to the Institute, which remain currently in place. A charter

Confers independent legal personality on an organisation and defines its objectives, constitution and powers to govern its own affairs (Privy Council, 2019).

Although subject to the general law, a chartered organisation is self-regulating, but any amendments to the charter itself can only be made by the Queen in Council and changes to by-laws have to be approved by the Privy Council, including changes to membership categories and criteria. Any amendments have to be seen to be for the public benefit. All this implies a clear obligation to work for the public good, including acting in an ethical manner. In addition, Government regulates its qualifications via the national regulatory body.

The Institute has a statutory right to be consulted by Government on matters that pertain to the profession and it is expected to be active in the public affairs arena. An example of where this has taken place is in the registration of lobbyists. As with other professional bodies, the Institute is expected to be active internationally and here its membership of the Global Alliance is important.

For CIPR members, the professional Code of Ethics becomes doubly important since it is enshrined as binding on members in the By-Laws. In the detailed Regulations it is linked to the obligation to work for the public good, building trust and transparency being key elements. The chartered mark is also a public indicator of the highest standards of professionalism and competence and the By-Laws require the Institute to keep a separate register of chartered public relations practitioners.

\section{Discussion}

As an indicator of progress, this discussion section takes as a point of reference the CIPR's State of the Profession 2019 report (CIPR, 2019). Interviews with the current CEO and Director of Professional Development and Membership were also undertaken to confirm current trends and to inform anecdotal evidence. Details of the survey and interviews are given in the Methodology section.

As can be seen from the process outlined above, the Institute was challenged on a number of the basic tenets described in the literature as defining a profession: issues around barriers to entry, that is, the dismantling of discriminatory barriers; the status of practitioners, particularly chartered practitioners, because this affects the market and potentially social closure; the standard of its training and its oversight of certified programmes by other providers. This is not surprising given it is the responsibility of the Privy Council to ensure that aspirants meet the test of being a profession. That the Institute was able to satisfy these challenges is vindication of its application. However, legitimacy, and especially social acceptance and closure does not only depend on a profession meeting these technical requirements. As indicated in the literature (Edwards 2014, 2018; Edwards and Pieczka, 2013; Bourne, 2019), legitimacy has to be achieved at the macro, meso and micro levels and these come together in the legitimation, or otherwise of the professional body because it is the institutional representative of the collective membership in society, and therefore to organisations as part of society. 
On the issue of diversity, there have been numerous initiatives to broaden the intake to the profession and to retain those minorities who enter. The Institute launched its first diversity policy in 2005 and since then has worked singly and with other organisations such as the Taylor Bennett Foundation ${ }^{3}$. However, ethnic minorities are still under-represented with the State of the Profession 2019 report showing than nine in ten $(92 \%)$ now classify themselves as white, compared to $88 \%$ in 2018 and $90 \%$ in 2017 . Likewise, although it is predominantly female, men are over-represented at senior levels: the profession is two-thirds (67\%) female, but men take nearly $44 \%$ of the most senior roles. Furthermore, the gender pay gap persists although it is decreasing: in 2019 it was $£ 5,202, £ 1,523$ less than in 2018. The number of people with disabilities in the profession is very low and the social class make-up is of deep concern with the profession having $28 \%$ of respondents from fee-paying schools, four times the national average and this is getting worse with the figure being $16 \%$ in 2016 . Added to this, there is a distinct preponderance of membership based in and around London and given many large organisations and Government departments are headquartered there, it is a reasonable assumption that there are more senior leaders in the capital.

In terms of professional accreditation, individual chartered status, which is the highest level of accreditation, was thought to be an attractive title for practitioners to aspire to, but numbers have remained relatively low with 312 people having qualified at the time of writing. However, enquiries with the CIPR revealed that there are a further 1401 Accredited Practitioners, which is the second highest level of professional accreditation and this indicates a level of positivity towards formal accreditation. Accredited PR Practitioner status is awarded to members who have completed two consecutive cycles of CIPR Continuing Professional Development.

Again the literature stresses the importance of those within professions enacting the role (Deephouse and Suchman, 2008; Lawrence and Suddeby, 2006; Scott, 2008; Edwards, 2018), but it appears that within the profession itself there is no great appetite to claim a professional identity at the highest level. However, the CEO of the CIPR believes there has been a change in attitude about chartered public relations practitioner status with an increase in interest in chartership being evident over the last two years. For example, a new PDF on the website launched in September 2018 achieved 12,000 downloads in nine months. Furthermore, those obtaining Chartered Practitioner status have become a strong advocacy body and their numbers are such that they are beginning to have an influence on the wider membership.

The two issues mentioned above, diversity and the numbers of those seeking the highest level of professional accreditation, are key to the closure arguments advanced in the literature. Certainly, in the UK, the barriers to entry and progression are replicated in other professions (Saks, 2015), but while many in other professions strive for the highest level of accreditation because it is essential for progression and is a socially accepted marker of professional respectability (Edwards, 2018), within the public relations profession it appears it is not viewed as such. As such, social closure is put at risk by the profession itself as well as by external threats (see below).

In addition, it was thought that the achievement of chartered status would be a significant milestone in the professional project for public relations in the UK. Its actual achievement through public test and the associated powerful symbolism of the Royal Charter itself would help to enhance its reputation, secure its legitimacy and lead to a level of social closure. Again, the State of the Profession 2019 report ranks 'not being seen as a professional discipline' as being the third biggest challenge facing the profession behind 'changing social 
and digital landscape' and 'under-representation of public relations practitioners at board level'. This point again reflects the literature discussion about social closure being achieved when societal, and organisational as well as individual legitimacy becomes a given.

There is also much anecdotal evidence (corroborated by the CIPR CEO) that public relations is still as excoriated as it has been in the past and this is often linked to the recurrent ethical challenges outlined in the literature review. The Bell Pottinger affair in South Africa (Economist, 2017) was a severe blow because a number of those involved were UK based and the company was headquartered in the UK. The action of the professional body to discipline individual members was seen as slow and inadequate and contrasted unfavourably to the trade body (PRCA), who quickly expelled the consultancy from its ranks and was able to do so, because the wrongdoing of the corporate body of the consultancy was evident. The culpability of individuals was by no means as apparent and the Institute's own disciplinary procedures were framed in such a way as to require certain processes to be fulfilled which, in this case, took some time. In addition, because public relations is not a closed profession, the public mind finds it difficult to distinguish between those who call themselves public relations practitioners but are not members of the professional body, and those who are and who are bound by its Code of Ethics. The CIPR cannot discipline non-members, but it was not quick enough to comment on the principles at stake. The State of the Profession 2019 ranks 'unethical public relations practice' as the sixth largest challenge the profession faces and the CEO's opinion is that the CIPR needs to show more leadership on ethical and public interest issues in the future.

The view of the author is that social closure as expressed in the public discourse and in the media, seems as distant as it was before the charter was obtained. The pejorative terms in common use such as 'only a PR exercise', or 'spin doctor' do not appear to be used any the less. The CIPR's CEO corroborates this opinion.

The DfES also posed a challenge around qualifications and training, including continuing professional development. The numbers of students taking CIPR recognised courses at both undergraduate and postgraduate level is falling according to the CIPR's Director of Professional Development and Membership, although it is difficult to be precise because a number of courses are hybridising to encompass more than one communication discipline. The State of the Profession 2019 shows that $62 \%$ of respondents have a first degree in a subject other than public relations or communication, and only $14 \%$ have. $13 \%$ state they have a Masters degree in public relations or communication.

The CIPR is a member of the Federation of Awarding Bodies (FAB) and has its own professional courses. The intake to the CIPRs certificate and diploma have also declined according to the CIPR's Director of Professional Development and Membership, but the State of the Profession report (CIPR, 2019) indicates that $45 \%$ of respondents have professional qualifications in public relations. Given the Certificate and Diploma programmes had been launched just six years before the charter application, this indicates good progress. Evidence from the CIPR is that the number of CIPR Corporate Affiliate organisations taking out group membership is increasing, and these employers want shorter, skills-based courses, often bespoke to their industry and delivered on-site, as opposed to qualifications that take longer to acquire and have a broader curriculum, including management topics. This is partly for financial reasons, but also because of uncertainty about how the profession will develop over the next period given the increasing use of AI and the changing role that professionals are now required to undertake as the communicative 
disciplines converge. A disappointment for the Institute is that the courses offering more strategic insights are less in demand than those catering for immediate skills requirements.

As an indication of progress however, the State of the Profession 2019 reports that chartered practitioners earn on average, $£ 18,000$ more than the average respondent (but this may reflect their seniority in some part), and those with a professional qualification earn on average $£ 3,800$ more. Interestingly, full-time CIPR members earn $£ 2,963$ more than nonmembers. It seems then that Larson's proposition of market advantage for professionals (Larson, 1997; 2012) holds in this case.

Although and interestingly, not challenged as part of the charter application process, jurisdictional boundaries continue to be contested. However, the CIPR has taken a more aggressive policy lead in a number of areas. For example, Artificial Intelligence (AI) was mentioned earlier and, according to the CIPR's CEO, the CIPR is acknowledged as the leading public relations professional association in the world on this topic. However, there is no doubt that in the communicative professions, marketing, especially with its control of customer relationship software is taking the lead on big data. Given the transformational effect that AI is having on working practices, this is a concern. There is opportunity, however, for an ethical role for public relations as the discipline with oversight for relationships as a whole. This is a topic too large to cover in this article, but it does relate to the fluidity of jurisdictional boundaries covered in the literature. A living, dynamic profession needs to be alert to jurisdictional threats, but it also requires the agility to capitalise on new opportunities for changing and expanding its role.

In summary, this discussion has shown that while there has been progress on some fronts, such as pay disparity and the overall numbers of those qualified in public relations, the four areas identified in the literature, jurisdictional boundaries; closure; body of knowledge and education, and ethics, and mirrored by the DfES concerns, remain live challenges for the Chartered Institute of Public Relations.

\section{Conclusions}

It is impossible to know what would have happened to the standing of the profession if chartered status had not been achieved, but as the discussion above shows, while it has not had the impact in a number of areas that was envisaged, in others it has: the professional project continues.

Looking back at the original documents, there is a profound sense of déjà vu. Some of the topics for discussion and the challenges apparent in 2004 remain current: diversity, education and parts of training being cases in point.

Despite the charter, there are constant battles still being fought over professional jurisdiction, with marketing continuing to encroach as well as management consultancy. This latter group are of particular concern. As the value of the intangible asset base of organisations increases and the fight for legitimacy and 'voice' intensifies, the importance of public relations or 'communication' is being increasingly recognised. Management consultants, who appear to have more credibility, are moving into this space. Their credibility is, ironically, not because of their demonstrated expertise, but because these consultants are often attached to professional services firms of lawyers and accountants, professions who have gained legitimacy and social closure. 
There are new arrivals too: behavioural economists and organisational psychologists to name but two.

Issues remain with the legitimacy of the profession. 'Working for the public good' is not a natural descriptor of the public relations profession for most people. The constant stream of negative media and stories from other sources, many of which are supported by evidence, indicates that the profession's moral compass is not always set to True North. Profit and supposed client interest trumps the public interest too often in the public mind.

The DfES desired to see more continuing professional development in management and leadership, but this is still all too often sidelined for skills training. A consequence of this in not only practitioners potentially lack these particular capabilities, but it unfortunately has the effect of confirming the practice in the technical role rather than that of the strategic adviser (CIPR, 2019). It is therefore, not over-stretching the evidence to conclude that the profession's progress to the long-desired position at the Board table is being inhibited and will be until it pursues the path to professional accreditation with equal zeal as its erstwhile peers around the Board table.

For those who initiated the process, obtaining chartered status was always a point in a journey not a destination. There may not have been as rapid progress as desired, but there is progress. Salaries are rising and demand for competent practitioners is buoyant. The Trusted Adviser role is highly valued and those at the top of the profession can expect to be well rewarded. There are more women in senior positions. Combined with these tangible denoters of success, is a spirit of optimism in the profession as a whole. It does have something important to contribute in a turbulent world that is finding itself fragmenting and confronting huge challenges such as climate change and the threat and reality of pandemics. It can contribute to positive relations and it can make a difference in society by being a source of reliable information and a beacon for proper conduct.

This article has highlighted and discussed the principal legitimacy challenges that faced the profession when it applied for a Royal Charter in the UK and reflects on progress on them in the following years. In identifying the widening and closing gaps relating to these challenges, a number of key issues that form the consistent and persistent threats to legitimacy have been discovered. These areas set a fruitful research agenda for the academy. For the practice, they demand radical examination and action if the aspiration of social closure is to be achieved.

Acknowledgement: the assistance and support of the Chartered Institute of Public Relations in preparing this article is fully and thankfully acknowledged.

Notes.

1. 'Profession' is a contested label as far as its application to public relations is concerned with other terms such as 'craft', 'occupation,' 'industry' 'para profession' being preferred and justified by others. However, in the context of this article it is deemed by the author to be the most appropriate term since the achievement of chartered status gives it formal recognition as a profession, in the UK at least.

2. The Global Alliance is the confederation of professional associations worldwide and represents some 200,000 individual practitioners who are all members of professional associations. 
3. The Taylor Bennett Foundation runs training and mentoring programmes to encourage black, Asian and ethnic minority graduates to pursue a career in public relations. See http://www.taylorbennettfoundation.org/abouttbf/

\section{References}

Abbott, A. (1988), The System of the Professions: An Essay on the Division of Expert Labor. University of Chicago Press, London.

Bourne, C. (2019), "The public relations profession as discursive boundary work", Public Relations Review, Vol. 45, No. 5, p.101789, doi.org/10.1016/j.pubrev.2019.05.010

Brock, D.M. and Saks, M. (2016), "Professions and organizations: a European perspective", European Management Journal, Vol. 34, No. 1, pp 1-6, doi.org/10.1016/j.emj.2015.11.003

CIPR (Chartered Institute of Public Relations) (2019). State of the Profession 2019. London: CIPR, available at https://www.cipr.co.uk/sites/default/files/11812\%20State $\% 20$ of $\% 20$ Profession v12.pdf

Cook, T. (2001), "Archival science and postmodernism: New formulations for old concepts", Archival Science, Vol. 1. No, 1, pp. 3-24, doi: 10.1007/BF02435636

Commission for Public Relations Education (2017), "Fast-forward: Foundations and future state. Educators and practitioners", available at http://www.commissionpred.org/commission-reports/fast-forward-foundations-futurestate-educators-practitioners/

Deephouse, D.L. and Suchman, M. (2008), "Legitimacy in organizational institutionalism", in Greenwood, R, Oliver, C, Sahlin, K. and Suddaby, R. (Eds.), The Sage Handbook of Organizational Institutionalism, Sage, Thousand Oaks, pp.49-77.

Dinan, W. and Miller, D. (2007), Thinker, Faker, Spinner, Spy: corporate PR and the assault on democracy, Pluto Press, London.

Doorly, J. and Garcia, H.F. (2010), Reputation Management, Routledge, New York

Economist, The (2017), "Scrambled in Africa: A famous PR Firm suffers a PR disaster Pottinger", The Economist, September 7, available at https://www.economist.com/britain/2017/09/07/a-famous-london-pr-firm-suffers-a-prdisaster (accessed June 10, 2019)

Edwards, L. (2014), “Public relations' origins: Definitions and history”, in Tench, R. and Yeomans, L. (Eds.), Exploring public relations. (3rd ed.), Pearson Education Limited, Harlow, pp. 3 - 20.

Edwards, L. (2018), Understanding Public Relations: Theory, Culture and Society, Sage, London.

Edwards, L. and Pieczka, M. (2015), "Public relations and 'its' media: exploring the role of trade media in the enactment of public relations' professional project2, Public Relations Inquiry, Vol. 2, No. 1, pp. 5-25, doi: 10.1177/2046147X12464204.

Fitch, K. (2014), "Professionalisation and public relations education: industry accreditation of Australian university courses in the early 1990s". Public Relations Review, Vol. 40, No. 4, pp. 623 - 631, doi:10.1016/j.pubrev.2014.02.015.

Friedson, E. (2001), Professionalism: the Third Logic, Polity Press, Cambridge.

Friedson, E. (1986), Professional Powers: A Study of the Institutionalization of Formal Knowledge, University of Chicago Press, Chicago. 
GA (Global Alliance) (2018), "Global Capability Framework", available at https://www.hud.ac.uk/media/assets/document/research/globalcapabilitiesinpublicrelatio nsandcommunicationmanagementgcpr/global-capability-framework-brochure.pdf.

Gregory, A. \& Fawkes, J. (2019), “A global capability framework: Reframing public relations for a changing world", Public Relations Review, Vol. 45, No.3, 101781, doi.10.1016/j.pubrev.2019.05.002.

Gregory, A., Invernizzi, E. \& Romenti, S. (2013), "Institutionalization, organisations and public relations: a dual process", in Sriramesh, K., Zerfass, A. and Kim, J-N. (Eds.), Public relations and commination managemen, Routledge, New York, pp. 268 - 282.

IPR (Institute of Public Relations) (2003), "Royal Charter: note by Director General”, IPR Executive Committee, $10^{\text {th }}$ July 2003, CIPR archives.

IPR (Institute of Public Relations) (2004a), "Petition to the Queen", CIPR archives.

IPR (Institute of Public Relations) (2004b), "IPR members approve Charter application", CIPR Press release, $25^{\text {th }}$ June 2004, CIPR archives.

Johnson, T. (1972), Professions and Power, Macmillan, London.

King, M. (2012), "Working with/in the archives", in Gunn, S., and Faire, L. (Eds.), Research methods for history, Edinburgh University Press, Edinburgh, pp. 13-29.

Larson, M.S. (1977), The Rise of Professionalism: A Sociological Analysis. University of California Press, London.

Larson, M.S. (2012), The Rise of professionalism: Monopolies of Competence and Sheltered Markets, Transaction Publishers, Piscataway.

Lawrence, T.B., \& Suddaby, R. (2006), "Institutions and institutional work", in Clegg, S.R., Hardy, C., Lawrence, T.B. and Nord, W.R. (Eds.), The Sage Handbook of Organizational Institutionalism, Sage, Thousand Oaks, pp.215-254.

Macdonald, K.M. (1995), The sociology of the professions, Sage, London.

L'Etang, J. (2008), "Writing PR history: Issues, methods and politics", Journal of Communication Management, Vol. 12, No. 4, pp. 319-335, doi: $10.1108 / 13632540810919783$.

Merkelsen, H. (2011), "The double-edged sword of legitimacy in public relations", Journal of Communication Management, Vol. 15, No. 2, pp. 25-143, doi: Miller, D. \& Dinan, W. (2008), A Century of spin: how public relations became the cutting edge of corporate power, Pluto Press, London.

Pieczka, M. and L'Etang, J. (2006), "Public Relations and the Question of Professionalism”, in L'Etang, J. and Pieczka, M. (Eds.), Public Relations: Critical Debates and Contemporary Practice, Lawrence Erlbaum Associates, Mahwah, pp. 265-278.

Privy Council (2003), Letter to Department of Trade and Industry, June, 18, 2003, CIPR archives.

Privy Council, (2019), "Royal Charters", available at https://privycouncil.independent.gov.uk/royal-charters/

Saks, D. (2012), "Defining a profession: the role of knowledge and expertise", Professions and Professionalism, Vol. 2, No. 1, pp. 1-10, doi: 10.7577/pp.v2i1.151.

Saks, D. (2015), "Inequalities, marginality and the professions", Current Sociology Review, Vol. 63, No. 6, pp. 850-868, doi: 10.1177/0011392115587332

Sandhu, S (2009), "Strategic communication: An institutional perspective", International Journal of Strategic Communication, Vol. 3, No. 2, pp. 72-92, doi:10.1080/15531180902805429.

Scott, W.R. (2008), Institutions and Organizations: Ideas and Interests, Sage, Los Angeles. Stauber, J. \& Rampton, S. (2004), Toxic Sludge is Good for You, Robinson, London.

Suchman, M.C. (1995), "Managing Legitimacy: Strategic and Institutional Approaches", Academy of Management Review, Vol. 20, No. 3, pp. 571-610, doi: 10.2307/258788 
Taylor, M. \& Kent, M.L. (2016), "Towards legitimacy and professionalism: a call to repeal the Gillett Amendment", Public Relations Review, Vol. 42, No. 1, pp. 1-8, doi:10.1016/j.pubrev.2015.09.012

Waeraas, A. (2007). "The Re-enactment of Social Institutions: Max Weber and Public Relations", Public Relations Review, Vol. 33, No. 2, pp. 281-286, doi:10.1016/j.pubrev.2007.05.007

Wylie, F.W. (1994). "Commentary: Public Relations is Not Yet a Profession”. Public Relations Review, Vol. 20, No. 1, pp. 1-3, doi:10.1016/0363-8111(94)90109-0

About the Author

Anne Gregory (PhD) is Professor of Corporate Communication in the Department of Management at the University of Huddersfield. She is an internationally renowned teacher and researcher, holding Adjunct and Visiting Professor roles at the Universities of Navarra in Spain and RMIT and UTS in Australia and leading numerous international research projects. She is a former President of the CIPR in the UK, former Chair of the Global Alliance of Public Relations and Communication Management and has been awarded the CIPR Sir Stephen Tallents Medal and the IPR Pathfinder Award. She is currently a Reviewer of Government Communication, appointed by the UK Prime Ministers' and Cabinet Office. 